Biografistyka Pedagogiczna

Rok 2 (2017) nr 1

ISSN 2543-6112; e-ISSN 2543-7399

DOI: 10.36578/BP.2017.02.25

Ryszard Skrzyniarz

\title{
Źródła poznania drogi osobistego rozwoju, zainteresowań i działalności Edmunda Bojanowskiego - omówienie edycji źródeł
}

* Ryszard Skrzyniarz - dr hab. prof. KUL, kierownik Katedry Biografistyki Pedagogicznej Katolickiego Uniwersytetu Lubelskiego Jana Pawła II, skrzyniarz@kul.pl.

(Prace, szkice i notatki Edmunda Bojanowskiego. Inedita, t. 1-2, red. Edward

Gigilewicz, s. Maria Loyola Opiela, Lublin 2016, t. 1, s. 891, t. 2, s. 1006, plus Prace, szkice i notatki Edmunda Bojanowskiego. Inedita. Indeksy, opracowała Weronika Gigilewicz, Lublin 2016, s. 63)

Sources of Knowledge about Edmund Bojanowski's Personal Development, Interests and Activities:

\section{A Discussion about the Edition of Sources}

Edmund Bojanowski (1814-1871) ${ }^{1}$ był świeckim założycielem zgromadzenia zakonnego, które zajęło się pomaganiem ubogim i chorym, wychowaniem dzieci (zwłaszcza biednych, sierot i opuszczonych), przygotowaniem religijnym dziewcząt do pełnienia przyszłych ról i obowiązków, pojmowanych jako droga prowadząca do Boga.

Po studiach, przerwanych z powodu choroby, powrócił w rodzinne strony, gdzie poświęcił się pracy społecznej, starając się niwelować skutki nędzy ludu wiejskiego. Zakładał szkoły, sierocińce i biblioteki. W 1849 r. podczas epidemii cholery w Gostyniu odwiedzał chorych, na różne sposoby pomagał im, zwłaszcza najuboższym, szczególną troską otoczył dzieci. Zorganizował szpital i sierociniec, do pracy w nim sprowadzono siostry miłosierdzia z Poznania i złożono fundusz na ich utrzymanie - w ten sposób powstał Instytut Gostyński, którym opiekował się do 1857 r., starając się zabezpieczyć
1 Edmund Wojciech Stanisław Bojanowski (ur. 14 listopada 1814 w Grabonogu, zm. 7 sierpnia 1871 w Górce Duchownej) działacz społeczny, twórca ochronek wiejskich, tłumacz, założyciel Zgromadzenia Sióstr Służebniczek Najświętszej Marii Panny, 13 czerwca 1999 r. w Warszawie przez Jana Pawła II został ogłoszony błogosławionym Kościoła katolickiego. 
jego potrzeby, począwszy od duchowych po materialne i organizacyjne. Czuwał nad wiernością przyjętemu kierunkowi pracy, zabiegał o fundusze i rozbudowę. Dostrzegał problem sierot, dzieci z ubogich rodzin wiejskich, które pozostawały bez opieki i były narażone na niebezpieczeństwa zagrażające ich życiu i rozwojowi. Widział także ich nędzę materialną i moralną. Pragnął zaradzić potrzebom wsi polskiej poprzez tworzenie ochronek i włączanie do służby w nich wiejskich dziewcząt, rozwijając metodę apostolstwa w środowisku przez osoby wywodzące się z niego.

3 maja 1850 r. Bojanowski wraz z gospodynią wiejską, Franciszką Przewoźną, założył ochronkę wiejską w Podrzeczu koło Gostynia. Wydarzenie to uważa się za początek Zgromadzenia Sióstr Służebniczek Najświętszej Maryi Panny, do którego przyjmował proste, wiejskie dziewczęta. Kształcił je i formował, przekazał im swoją filozofię opartą na wartościach chrześcijańskich, pielęgnowanych przez lud i powierzył sprawę wychowania ludu.

Bojanowski rozwijał swoją myśl pedagogiczną i wprowadzał ją w praktykę, wykorzystywał to tego swój wcześniejszy dorobek, wiedzę i talent pisarski. Jego publikacje ukazywały się w licznych czasopismach, m.in. na łamach "Przyjaciela Ludu” (1834-1849), „Marzanny” i „Melitele”. Dla potrzeb ochron

1 Piosnki wiejskie dla ochronek. $Z$ przygrywka T. Lenartowicza, Poznań 1862.

2 Starodawne przystowia dla Ochronek, Poznań 1862

3 „Pokłosie. Zbieranka literacka na korzyść sierot", Leszno 18521853, Poznań 1854-1856, 1862

4 „Rok Wiejski”, Gniezno-Ostrów 1860-1862. w 1862 r. wydał Piosnki wiejskie dla ochronek ${ }^{1}$ i Starodawne przysłowia dla ochronek ${ }^{2}$. Prowadził także własną działalność wydawniczą, a najważniejszą jego inicjatywą na tym polu był noworocznik „Pokłosie. Zbieranka literacka na korzyść sierot", wydawany w latach $1852-1862^{3}$. Wspólnie z ks. Hilarym Koszutskim w latach 1860-1862 wydawał czasopismo dla ludu „Rok Wiejski” ${ }^{4}$, w którym publikował, przeważnie anonimowo, także własne utwory. Podejmowane przez Bojanowskiego we współpracy ze zmartwychwstańcami (Piotr Semenenka, Hieronim Kajsiewicz, Jan Koźmian) poszukiwania systemu wychowania, właściwie służącego sprawie narodowej, znalazły ostateczny kształt w idei ochronek

5 Reguła Zgromadzenia Sióstr Stużebniczek Boga-Rodzicy-Dziewicy Niepokalanie Poczętej, Poznań 1867. wiejskich i Regule ${ }^{5}$ utworzonego w celu realizacji tej misji wychowawczej, misji zgromadzenia służebniczek.

Bojanowski pozostawił po sobie wiele rękopisów, które stały się źródłem do omawianej edycji. Jego spuścizna, niemal całość rękopisu „Notatek”, przechowywana jest 
w Archiwum Głównym Służebniczek Dębickich w Dębicy. Niewielki zbiór kart zachował się również w Archiwum Głównym Służebniczek w Luboniu.

Zachowana w zbiorach służebniczek spuścizna bł. Edmunda Bojanowskiego obejmuje jego korespondencję (1829-1871), „Dziennik” (1853-1871) oraz zbiór luźnych kartek, tzw. Notatki. Dopełniają je materiały cudze, wpisy, akta urzędowe oraz zapiski prywatne (m.in. z czasu studiów, rodzinne i finansowe).

Dziennik Bojanowskiego po trzykrotnym wydaniu wyboru $^{6}$ został opracowany i opublikowany w całości przez Leonarda Smołkę. Rękopisy zachowanych 989 listów, w tym 310 listów napisanych i wysłanych przez Edmunda Bojanowskiego oraz 679 pism adresowanych do niego, zostały opracowane i wydane jako Korespondencja Edmunda Bojanowskiego z lat 1829-18718.

"Notatki" Edmunda Bojanowskiego to zasób źródłowy zebrany w 32 teczkach rękopisów na luźnych kartach i w brulionach, na kartach zszytych nitką bądź też w oprawnym notesie. Łącznie zespół obejmuje ponad 1700 kart różnej wielkości zapisanych jedno- i dwustronnie. Bojanowski notatki tworzył głównie na pełnych arkuszach papieru, składając je na mniejsze kawałki.

W edycji przyjęto układ merytoryczny, i stąd spuścizna rękopiśmienna Edmunda Bojanowskiego została usystematyzowana w dziewięciu działach, ukazujących zasadnicze obszary jego aktywności pisarskiej.

Tom pierwszy zawiera: przedmowę, od wydawcy, wstęp,
6 E. Bojanowski, Dziennik 18531871, wybór, wstęp i przypisy A. i T. Szafrańscy, Warszawa 1988 (wyd. 2, poprawione i uzupełnione, Warszawa 1999); w języku włoskim: Diario del Servo di Dio 1853-1871, w: Beatificationis et canonizationis Servi Dei Edmundi Bojanowski, viri laici, fund. Congreg. Ancillarum B. M. V. Imm. (1814-1871). Positio super virtutibus ex officio concinnata, vol. 1, Romae 1996, s. 602-1060.

7 E. Bojanowski, Dziennik. Wydanie kompletne rękopisu i luźnych kartek Dziennika wraz z zapisami dziennymi zespołu notatek pt. Ochronka podrzecka 1851-1853 i relacją s. Elżbiety Szkudłapskiej Ostatnie dni życia i pogrzeb. Objaśnit, skomentował i wstępem poprzedził L. Smołka, t. 1-4, Wrocław 2009.

8 Korespondencja Edmunda Bojanowskiego $z$ lat 1829-1871. Objaśnit, skomentował i zarysem monograficznym poprzedził Leonard Smołka, Wrocław 2001, t. 1: Listy Edmunda Bojanowskiego $z$ lat 1836-1871, t. 2: Listy do Edmunda Bojanowskiego $z$ lat 1829-1868. notę edytorską, wykaz skrótów ogólnych, wykaz skrótów bibliograficznych, symbole graficzne i wykaz ilustracji (s. V-XXVI). W części edycyjnej pierwszą grupę zagadnień obejmują prace historyczne i literackie (s. 3-231), są to prace literackie pozostawione przez Bojanowskiego w całości lub w znacznej części w czystopisie (w przypadku zachowania niepełnego czystopisu braki uzupełniano lub rekonstruowano na podstawie brudnopisu). Drugą grupę stanowią kwestie wychowania w ochronkach (s. 235-604) - opracowania 
z zakresu teorii wychowania. Problematyka dotycząca spraw organizacyjnych i gospodarczych została ujęta w trzeciej części (s. 607-743) - ukazuje praktyczne aspekty funkcjonowania ochronek i prowadzoną w nich pracę wychowawczą. Ostatnia z tego tomu - czwarta grupa tematyczna została zawarta w wypisach i szkicach o tematyce religijnej (s. 747-886). Na końcu zostały zamieszczone rysunki zawierające szkice, projekty i ilustracje.

Drugi tom obejmuje cztery rozdziały. W piątym rozdziale zostały zawarte materiały i szkice do prac etnograficznych i historycznych (s. 5-441), zawiera on zarówno oryginalne teksty autora, jak sporządzane przez niego wypisy z prac innych badaczy historii i kultury słowiańskiej. Następny obejmuje zbiory pieśni i piosenek (s. 445-660) - zebrano tu rozproszone po różnych zespołach fragmenty opracowania teoretycznego na temat pieśni i piosenek, także zbiory samych tekstów i ich wykazy. W siódmym są zawarte notatki z redakcją czasopism (s. 663-735). Oprócz wykazów artykułów i spisów współpracowników (aktualnych i pożądanych) znalazły się tutaj także zapiski ze sfery konceptualnej na temat czasopism, zwłaszcza próby opracowania artykułu wstępnego do planowanego czasopisma „Ochrona”. Rozdział ósmy to Excerpta i epitomaty (s. 739-871) dokumentuje podjęty w pierwszym okresie twórczości pisarskiej Bojnowskiego, jeszcze podczas studiów, zamysł tworzenia zbiorów obejmujących wypisy i streszczenia z dzieł innych autorów, które sam nazwał Excerpta i epitomaty. Dziewiąty dział obejmuje varia (s. 875-1003), wśród których znalazły się m.in. notatki dotyczące jego warsztatu pisarskiego (np. zapiski metodologiczne wyłączone z zespołu obejmującego jego prace literackie, wykazy i omówienia bibliograficzne), liczne zapiski o charakterze osobistym (wypis z Dziennika, rachunki i zestawienia finansowe), a także odnaleziony wśród archiwaliów o charakterze finansowym nieznany wcześniej list Bojanowskiego do ochronki w Jaszkowie.

Indeksy zawierają wstęp, indeks osobowy, indeks geograficzny i indeks rzeczowy. Obejmują one teksty główne i przypisy pochodzące od Bojanowskiego. Stanowią one integralną częścią edycji, co znacznie ułatwi korzystanie $\mathrm{z}$ tego narzędzia badawczego. Opracowania tego skomplikowanego zestawienia dokonała Weronika Gigilewicz.

Zespół redakcyjny podjął trud zebrania wszystkich rękopisów Bojanowskiego i ich edycji, aby przedstawić w nich jego myśl pedagogiczną i skupić cały dorobek w jednym miejscu. Posłuży on nie tylko badaczom historii zgro- 
madzenia, biografom czy pedagogom, ale przede wszystkim pomoże w oddaniu przedsięwzięć Bojanowskiego na tle epoki, wpływu innych myślicieli na jego idee i rodzącą się myśl pedagogiczną oraz tworzenie ochron, a także założonego zgromadzenia, które miało te cele realizować. Trud ten podjęła s. Maria Loyola Opiela znawczyni myśli pedagogicznej Bojanowskiego i Edward Gigilewicz specjalista od edycji źródeł. Oddali on do rąk czytelnika wspaniałe dzieło - źródło do życia i myśli bł. Edmunda Bojanowskiego.

Omawiana publikacja została doceniona przez Kapitułę Nagrody Stowarzyszenia Wydawców Katolickich „Feniks 2017” i została nagrodzona tym wyróżnieniem w kategorii „duchowość” za książkę wydaną w 2016 r. 